Article

\title{
Linkage between Water Level Dynamics and Climate Variability: The Case of Lake Hawassa Hydrology and ENSO Phenomena
}

\author{
Mulugeta Dadi Belete ${ }^{1,2,3, *}$, Bernd Diekkrüger ${ }^{1}$ and Jackson Roehrig ${ }^{2}$ \\ 1 Department of Geography, University of Bonn, 53115 Bonn, Germany; b.diekkrueger@uni-bonn.de \\ 2 Institute for Technology and Water Resources Management in the Tropics and Subtropics, \\ Cologne University of Applied Sciences, 50679 Köln (Deutz), Germany; Jackson.roehrig@fh-koeln.de \\ 3 Institute of Technology, School of Water Resources Engineering, Hawassa University, \\ Hawassa P.O. Box 005, Ethiopia \\ * Correspondence: mulugeta.belete9@gmail.com; Tel.:+251-46-212-29-71
}

Academic Editor: Yang Zhang

Received: 21 November 2016; Accepted: 27 February 2017; Published: 6 March 2017

\begin{abstract}
Lake Hawassa is a topographically closed lake in the Central Main Ethiopian Rift Valley. The water level of this lake has been reported to dramatically rise without falling back to the original level. The cause of this rise is not yet sufficiently investigated and subjected to this study. This study argues that the general variability in the lake level and its resultant rise has significant linkage to the temperature variability at the Pacific Ocean. The linkage between water level dynamics and climate variability was analyzed through the application of diverse statistical techniques. It comprises the Mann-Kendall trend analysis to test monotonic variations over time; sequential regime shift index (RSI) to detect significant shifts in the mean values of time-series records of lake level; and coherence analysis to investigate the linear relationship between ENSO index and records of local hydrology. Despite the multiple rises and falls, the results of the trend analysis revealed that the lake level experienced a significant resultant upward trend with Mann-Kendall $\tau$ values of $0.558,0.629$, and 0.545 (at $\alpha=0.05$ and $p<0.01 \%$ ) for monthly maximum, average and minimum values respectively. The sequential regime shift evidenced that most of the significant shifts coincide with the occurrences of ENSO events. Generally, the lake level tends to be high during El Niño and low during La Niña episodes. The typical examples are the coincidence of extreme historical maximum lake level to the strongest El Niño event of the century that occurred in 1997/98 and the lowest lake level record in the year 1975 with a strong La Niña year. The coincidence of climate regime shift in the Pacific Ocean in 1976/77 with an equivalent regime shift in the lake level is an additional confirmation for the possible climate-hydrology linkage. The likely involvement of anthropogenic factors (at least in modifying the effect of climate) is justified by the interplay between the non-trending rainfall and potential evapotranspiration and trending streamflow. The coherence analysis between 492 pairs of monthly step datasets of 3.4ENSO index and lake level changes is also found to have a significant linear relationship over frequencies ranging from 0.13 to 0.14 cycles/month or 1.56 to 1.68 cycles/year. This corresponds to a dominant average periodicity (coincident cycle) of about 7.4 months which is thought to be related to the time span of the two rainy season in the locality.
\end{abstract}

Keywords: Lake Hawassa; 3.4ENSO index; trend analysis; regime shift; coherence analysis; El Niño; La Niña 


\section{Introduction}

One of the most significant and broadly impacting effects of climate variability on lakes is the changes in water level. Such changes reflect an alteration of the lake water balance, which can result from changes in precipitation, surface runoff, ground water flow, and evaporation from the lake surface [1]. The water in a lake is balanced by the basic hydrological relationship in which the change in water storage is governed by the water input and output to the system [2].

In the 1960s, lakes throughout East Africa rose [3], resulting from a series of remarkably wet years $[4,5]$. The spatial extent and the magnitude of fluctuations were considered as a signal to major global climate change [6]. According to Arnell et al. [6] and Bergonzini [7], African lakes are known to be very sensitive to climate variations with special sensitivity of closed lakes. The impact of non-climatic factors on water level variability in Ethiopia was also reported by Görner et al. [8] and Belay [9].

Lake Hawassa, a topographically closed lake in the Central Main Ethiopian Rift Valley, has been experiencing a progressive rise in water level during the past two decades (1981-1998) [10,11]. The concern of this rise achieved its peak in the aftermath of the extreme flooding of the surrounding area as a result of extreme rise in 1998/99. According to WRDB [12] and WWDSE [11], the lake level rise and the associated surface expansion affected about 162 urban and 2244 farmers' households, 13 different organizations, water supply schemes, 10 ha of sand quarry, roads, and forest land. In monetary terms, the total physical damage was estimated to be $43,490,524$ Ethiopian birr (about $€ 5.4$ million).

Over the past few years, several researchers have studied the long-term water balance of Lake Hawassa, such as Gebreegiziabher [10], Ayenew [13], Deganovsky and Getahun [14], WWDSE [11], Ayenew and Gebreegiziabher [15], Gebremichael [16], and Shewangizaw [17]. Land use/cover changes have also been studied by Wagesho et al. [18], and WWDSE [11]. Despite the number of studies and their importance, the cause of lake level rise has not been concluded and not yet explicitly investigated.

The idea of "climate-hydrology link" was conceived in this study after the recognition of coincidence between the lowest lake level record in the year 1975 with a strong La Niña year and the maximum lake level in 1998 with the strongest El Niño year. La Niña and El Niño are anomalies in ocean surface water temperature. They are commonly termed as "teleconnections" [19].

Having the general objective to investigate the association between local hydro-climatic variables of Lake Hawassa hydro-system with the climate variability at Pacific Ocean, this study sets the following specific objectives:

- To analyze the long-term trends (variation over-time) and sequential regime shifts (variation across-time) for lake level, rainfall, streamflow, and potential evapotranspiration;

- To compare significant change points of the above hydro-climatic variables with the timing and intensity of North Pacific climate shifts/ El Niño/ La Niña occurrences; and

- To analyze the coherence between data series of Niño3.4 Index (N3.4) and Lake Hawassa water level.

\section{Methodology}

\subsection{Description of the Study Area}

Lake Hawassa watershed is located in the central North-East of the Ethiopian Rift Valley Basin (Figure 1) and covers an area of $1436.5 \mathrm{~km}^{2}$. It contains five sub-watersheds: Dorebafena-Shamena, Wedesa-Kerama, Tikur Wuha, Lalima-Wendo Kosha and Shashemene-Toga. The geographical co-ordinates of the watershed are $6^{\circ} 45^{\prime}$ to $7^{\circ} 15^{\prime}$ North and $38^{\circ} 15^{\prime}$ to $38^{\circ} 45^{\prime}$ East latitude and longitude respectively. Hawassa city, named after the lake, is located at $275 \mathrm{~km}$ south of the capital city-Addis Ababa and is established in the very eastern shore of the lake [20]. 


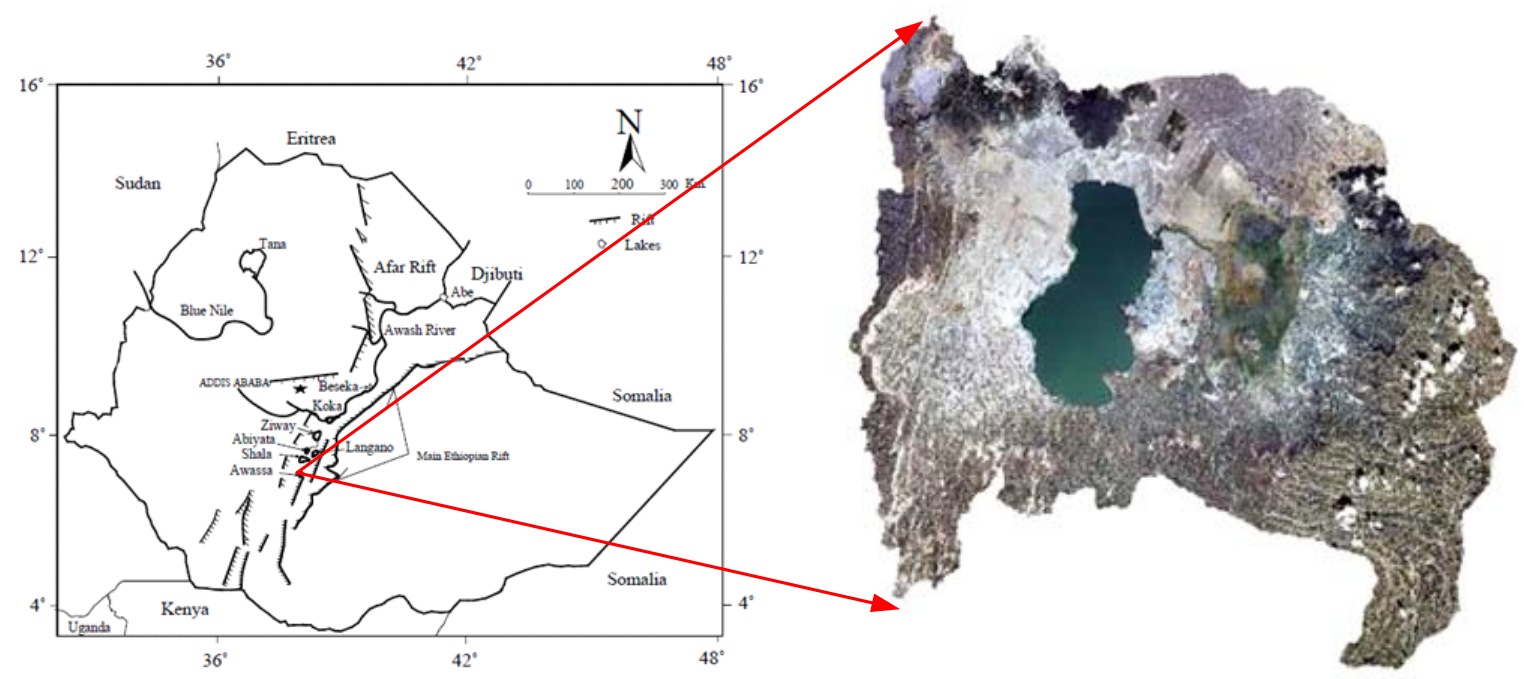

Figure 1. Location map of the study area (Source: Belete et al. [21])

According to MoWR [20], land use in the watershed is dominated by cultivation which occupies $66 \%$ of the land area with intensive cultivation. The major land cover splits into smallholder cultivation $(95 \%)$ mechanized cultivation (5\%) most of which is state owned. Although the lake water has been abstracted for supplementary irrigation, the total amount of water abstraction is negligible compared to all other water balance components.

According to Legesse et al. [22], the watershed is characterized by three main seasons. The long rainy season in the summer from June-September is known locally as Kiremt and is primarily controlled by the seasonal migration of the inter-tropical convergence zone (ITCZ), which lies to the north of Ethiopia at this period. The wet period represents $50 \%-70 \%$ of the mean annual total rainfall. The dry period (locally named as Baga) extends between October and February when the ITCZ lies to the south of Ethiopia [23]. During March and May, the "small rain" season (locally named as Belg) occurs when about $20 \%-30 \%$ of the annual rainfall falls. The climate in the area varies from dry to sub-humid according to the Thornthwaite's system of defining climate or moisture regions [24].

As computed from the long-term (1973-2010) rainfall record of Hawassa meteorological station, the annual average magnitude is computed to be $961 \mathrm{~mm}$ and distributed as $50 \%$ for Kiremt (June-September); 20\% for Baga (October-February) and 30\% for Belg season (March-May). Figure 2 shows the long-term average monthly distribution of rainfall and temperature at Hawassa meteorological station.

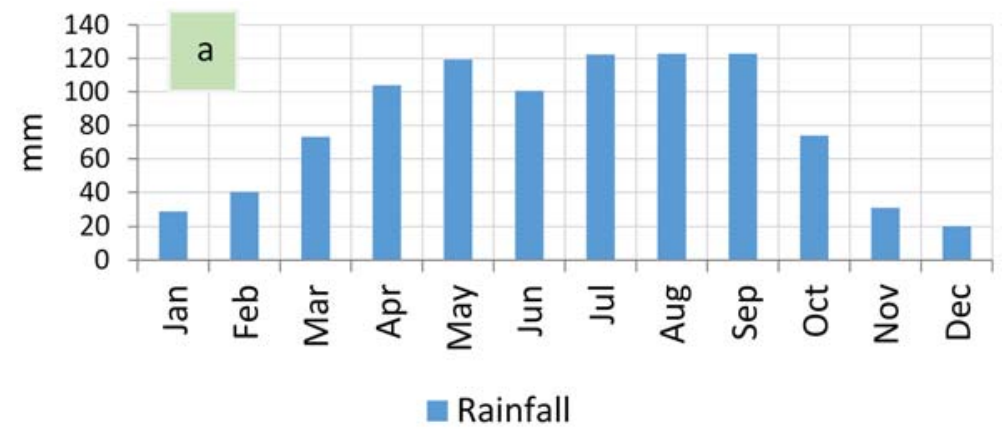

Figure 2. Cont. 


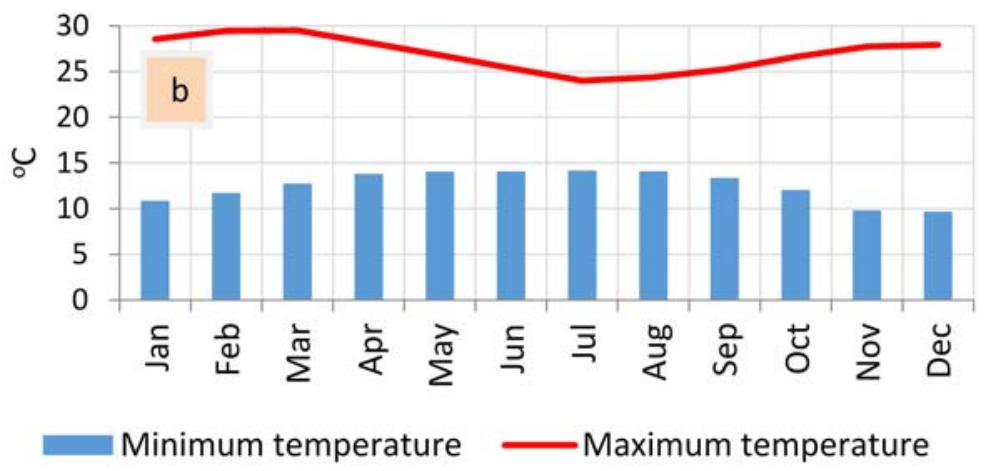

Figure 2. Distribution of monthly rainfall (a) and temperature (b) at Hawassa.

In term of topography, the majority of the watershed is flat to gently undulating but bounded by steep escarpments. The altitude ranges from $1680 \mathrm{~m}$ at Lake Hawassa to $2700 \mathrm{~m}$ on the Eastern escarpment: an altitude range of $1020 \mathrm{~m}$. Most slopes $(56 \%)$ are flat to gentle $(0 \%-8 \%)$ with a further $33 \%$ moderately sloping $(8 \%-30 \%)$ and only $5 \%$ steep to very steep $(>30 \%)$ [24].

\subsection{Data Availability}

As shown in Table 1, there exists fairly long sequence of hydro-climatic data for Hawassa meteorological station which is the nearest station for the lake. Other meteorological stations in the watershed have limited data. Data gaps are filled by linear interpolation throughout this study.

Table 1. The core set of hydro-climatic data employed in the study.

\begin{tabular}{|c|c|c|c|}
\hline Data Type & Temporal Scale & Period & Sources \\
\hline Lake level records & Daily & 1970-2010 & Ministry of Water Resources \\
\hline Streamflow & $»$ & 1980-2006 & $»$ \\
\hline Rainfall & $»$ & 1972-2010 & Meteorological Agency \\
\hline Temperature & $»$ & $1986-2006$ & » \\
\hline Wind speed & $»$ & 1986-2006 & $»$ \\
\hline Relative humidity & $»$ & 1986-2006 & $»$ \\
\hline Sun-shine hours & $»$ & 1986-2006 & $»$ \\
\hline
\end{tabular}

N.B. The water level records have been made from conventional local bench mark and time series data of the actual water level was derived by adjusting the records to the bathymetric map of the lake.

\subsection{Detection of Long-Terms Trends Using Mann-Kendall Test}

According to our knowledge, the statistical significance of long-term monotonic trend of Lake Hawassa water level had not been computed before. Statistical trend analysis is a hypothesis testing process in which the null hypothesis $\left(\mathrm{H}_{0}\right)$ states that there is no trend. Trend analysis enables to detect significant variations overtime. It is easily understood and communicated, and readily accepted due to its wide spread use [25]. In this study, the well-known Mann-Kendall (MK) statistical trend test $[26,27]$ was employed to investigate trends in time series data. It is a kind of non-parametric test and compares the relative magnitudes of sample data rather than the data values themselves. The technique also allows us to investigate long-term trends of data without assuming any particular distribution. The other advantage is its low sensitivity to abrupt breaks due to inhomogeneous time series. In this study, the $5 \%$ level of significance was considered $[28,29]$.

\subsection{Sequential Regime Shift Detection Using Regime Shift Index (RSI)}

The concept of "regime" in hydrology describes the temporal pattern of the variable under discussion over a period of time and "regime shift" was originally proposed in relation to oceanic 
ecosystem [30,31] to describe sudden drastic changes in temporal characteristics of a variable [11]. The definition of climatic regime shifts can be viewed as "differing average climatic levels over a multi-annual duration" [32]. Shifts in the mean are the most common type of shifts considered in literature [33,34].

A jump in a series that is detected by a regime shift test can imply changes in either climatic factors or watershed characteristics [35]. According to Breaker [36], change points occur where the changes are relatively abrupt. Formally, a change point exists at a time $t_{0}$, if all of the observations up to $t_{0}$ share a common statistical distribution, and those after $t_{0}$, share a different statistical distribution. Rodionov [33] introduced an algorithm for detecting sequential regime shifts in time series data based on sequential $t$-tests.

\subsection{Estimation of Coherence between ENSO Index and Lake Level Variability}

Time series data records of any two continuous variables suitable for computing a covariance, if of sufficient length for computing a stable fast Fourier transform (fft), can be transformed into the frequency domain for computation of a dimensionless squared spectral coherence. Transforming from the time to the frequency domain and computing the squared spectral coherence $(\mathrm{CH})$ provides frequency-stratified results that can be tested for statistical significance using the F-distribution [37]. Coherence, also known as coherency spectrum, or magnitude-squared coherence, is a widely used measure for characterizing linear dependence between two time series and classical books on time series analysis present coherence as "the frequency domain analogue of the autocorrelation function" [38]. Further information on spectrum analysis can be referred from books such as [39,40].

The use of spectral coherence analysis is quite recent in the area of hydrology. The coherence analysis in this study was made following the idea of Jenkins and Watts [41] and Bloomfield [42] where more detailed explanation about the techniques can be referred. This technique was employed to analyze the relationship between Niño3.4 index and lake level data series. The significance of coherence resulting from this technique suggests that changes in one series are related to changes in the other. As subjected to this analysis, the two phenomena are assumed to be ergodic (their statistical properties can be deduced from a single, sufficiently long, random sample of the processes) and the system functions linearly. A total of 492 pairs of monthly step time series data were undergone through spectral analysis for the explicit estimation of "coherency" between these series. The Niño3.4 index (N3.4), which is the average SST anomaly within the region $5^{\circ} \mathrm{S}-5^{\circ} \mathrm{N}, 170^{\circ}-120^{\circ} \mathrm{W}$ was used as a representative index for ENSO phenomena. This index is usually employed to predict rainfall in Ethiopia [43,44]. It is one of the most widely used ENSO index [45].

The presence of a trend in a time series data produces a spectral peak at zero frequency, and this peak can dominate the spectrum in that other important features are obscured [46]. Due to this, detrending should be part of the analysis. In this study, the time series were detrended using linear regression. The autocorrelations in the time series were also removed by differencing techniques with order 1.

For more reading about the Fourier transform, refer standard text books such as Jenkins and Watts [41]. Namdar-Ghanbari et al. [47] employed similar analysis to examine the relationships between ice, local climate and the teleconnections, Southern Ocean Oscillation (SOI), Pacific Decadal Oscillation (PDO), North Atlantic Oscillation (NAO), and Northern Pacific Index (NP).

As noted by Thomson and Emery [25], the final step in any coherence analysis is to specify the confidence limits for the coherence-square estimates. This step places the spectral results in a complete statistical context.

As presented by Namdar-Ghanbari et al. [47], the estimated coherencies are considered significant at the $99 \%$ and $95 \%$ level of confidence when they are larger than the critical value $\mathrm{T}$ derived from the upper $1 \%$ and $5 \%$ points of the F-distribution. 


\section{Results and Discussion}

\subsection{Result of Trend Analysis}

The visual inspection of Figure 3 uncovers the underlying variability of the observed lake level by suggesting that, beside the annual cycle, the overall oscillation does not show periodicity that may be associated to the local situation such as the hydrologically-closed nature of the lake in that the occurrence of an extreme event may consecutively manifest itself (residual effect) in response to the imbalance between inflow and outflow water balance components. The highest peak was observed in November 1998 (22.54 m) followed by October and December of the same year (22.49 $\mathrm{m} \mathrm{each})$. The lowest level in this year (June) $(21.8 \mathrm{~m}$ ) was greater than $92.5 \%$ of historical records. This particular year was known for its peak records in many parts of the world. The cases of Lake Abaya (another Rift Valley lake in Ethiopia) [48] and other lakes in this basin [21]; Lake Nasser (Egypt), Lake Chad, Lake Turkana, Lake Tanganyika, Lake Victoria, and Lake Mwero [49] are among the examples.

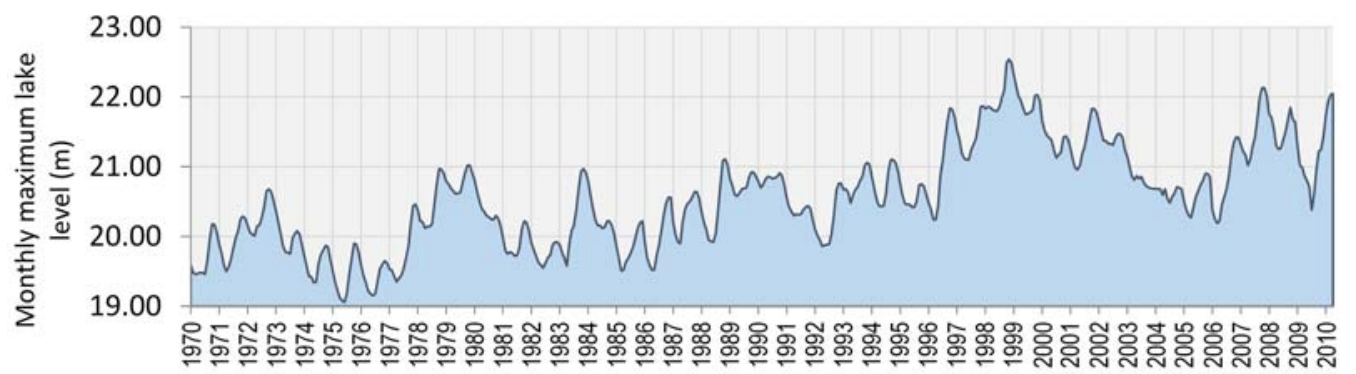

Figure 3. Hydrograph of monthly maximum lake level.

Despite the multiple rises and falls, the lake level experienced a significant resultant upward trend with Mann-Kendall $\tau$ values of $0.558,0.629$, and 0.545 (at $\alpha=0.05$ and $p<0.01 \%$ ) for monthly maximum, average and minimum values respectively. The ultimate evolution of increasing trend is not gradual and consistent in direction (monotonic) rather sharp rises and falls have been frequently appearing and such variations are likely to bias the monotonic trend. Similar comment was given by [46] in that the use of trend analysis in climate change research depends greatly upon the time period studied, and results can be biased when an abrupt climate change is observed during the study period.

Regarding the connection of ENSO events to the extreme values of observed lake levels, the 1998 record (historical maximum) can easily be justified for its connection to the worst El Niño event of the twentieth century [50,51] as measured by changes in the Pacific [52]. Globally, this El Niño year caused loss of approximately 35-45 billion USD [53]. In contrast, the lowest lake level was observed in 1975 which is likely linked to the two consecutive strong La Niña events of 1973-1974 (the strongest in the period 1950-2012) and 1975-1976.

\subsection{Results of Sequential Regime Shift Analysis}

\subsubsection{Lake Level Variability}

Figure $4 \mathrm{a}-\mathrm{c}$ demonstrate the observed annual average, maximum, and minimum lake levels have undergone a couple of sequential regime shifts reflecting the instability of the hydro-system. Synthesis of the RSI result for average lake level records is shown in Appendix A. 

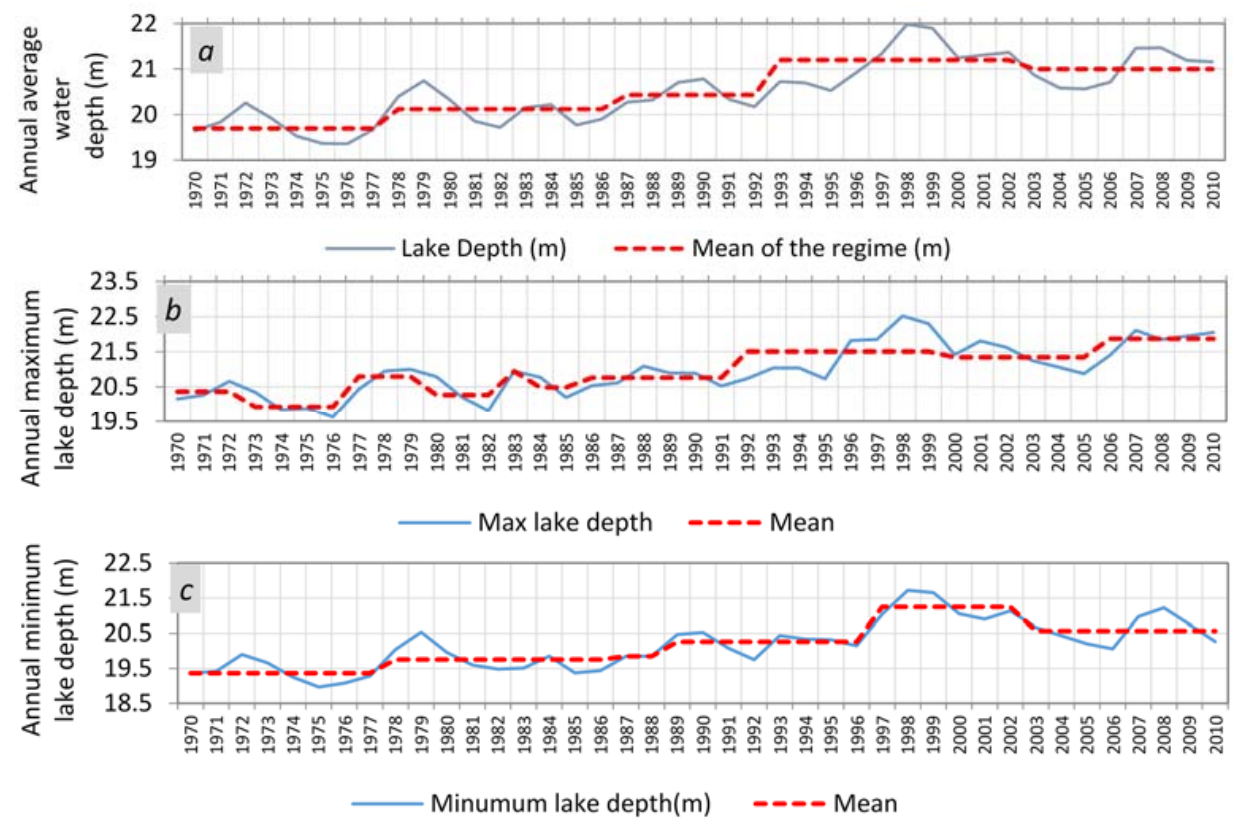

Figure 4. Sequential regime-shifts in annual lake levels (a) average; (b) maximum and (c) minimum.

The important aspect of the prevailing regime shifts lies on their occurrence in the year 1976-1978 (Figure 4a-c) which was known for the climatic regime shift period of the North Pacific [54,55]. The year 1977 also experienced the highest historical recorded annual total rainfall (1226 $\mathrm{mm})$. The maximum lake level has undergone a regime shift in 1983 (Figure 4b), which is likely to be associated with the devastating El Niño of 1983. The other smaller shift in mean value of lake level occurred in 1986 which was likely caused by moderate but prolonged El Niño of 1986-1987. Another connection that is manifested by the overlap of regime shift of Lake Hawassa water level and the North Pacific climate regime shift was observed in 1989 (Figure 4c) and Yletyinen et al. [55] reported that in 1989, a new regime shift (in the climate of the Pacific) had also occurred but the changes were not as remarkable or pervasive as in the 1976-1977.

The highest regime shift was observed in 1992, which showed an upward shift in mean value of the lake level from $20.43 \mathrm{~m}$ to $21.2 \mathrm{~m}$, implying a regime shift of $0.77 \mathrm{~m}$. This regime was extended up to 2002 and known for its frequent El Niño years of 1991-1992 (strong), 1994-1995 (moderate), and the 1997-1998 El Niño (strong). Swanson and Tsonis [56] also noted that climate shift occurred around 2001/2002 too and Lake Hawassa also experienced water level regime shift in this year. The relatively sustained maximum lake level regime extended from 1992 up to 1999 (Figure 4b) signifies the occurrences of three El Niños (strong, moderate, strong consecutively) without the occurrence of La Niña in between.

The general up ward shifts between 1978 and 1998 are in agreement with the work of Peterson and Schwing [57]. They identified the PDO (Pacific Decadal Oscillation) index, another index to be negative for most years during 1948-1976 and positive during 1977-1998. In addition, Niebauer [58] observed that before the regime shift, the occurrence of El Niño and La Niña conditions was about even. Since the regime shift, El Niño conditions are about 3 times more prevalent and this further signifies the effect of climate.

\subsubsection{Rainfall Variability}

Figure 5 shows the sequential regime shifts in annual rainfall at Hawassa meteorological station that represents the over-lake rainfall. As depicted by the figure, the rainfall time series shows high variability with nine distinct regimes over the study period. The relatively long and stable regime extended from 1986 to 1994 (upward shift) followed by regimes of 1999-2004 (downward) and 
2005-2010 (upward). The remaining regimes are short lived and most of the breaking points coincided with the occurrences of ENSO phenomena (1976, 1983, and 1994). The climate regime shift of North Pacific Ocean that occurred in 1976/1977 seems to manifest itself by causing an upward shift in both years. The annual total rainfall record of 1977 was the highest of the records (1226 mm). The shift in 1998 was also most likely linked to the transition from strong (1997-1998) to the two consecutive strong La Niñas (1998-1999 and 1999-2000).

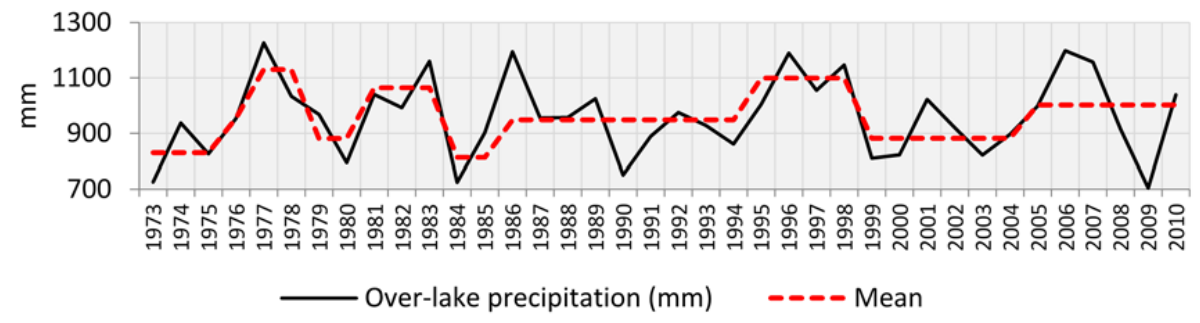

Figure 5. Regime shift of over-lake rainfall.

\subsubsection{Variability in Streamflow}

Figure 6 demonstrates the variability of stream flow of Tikur Wuha River (the only river draining into Lake Hawassa) across time. The Tikur Wuha River drains about $50 \%$ of the catchment while the rest of the catchment drains via ground water or ephemeral channel flow. The first breaking point occurred at 1986, which is known for its moderate El Niño. The years 1994 and 1997 are also another change points corresponding to the timing of ENSO events.

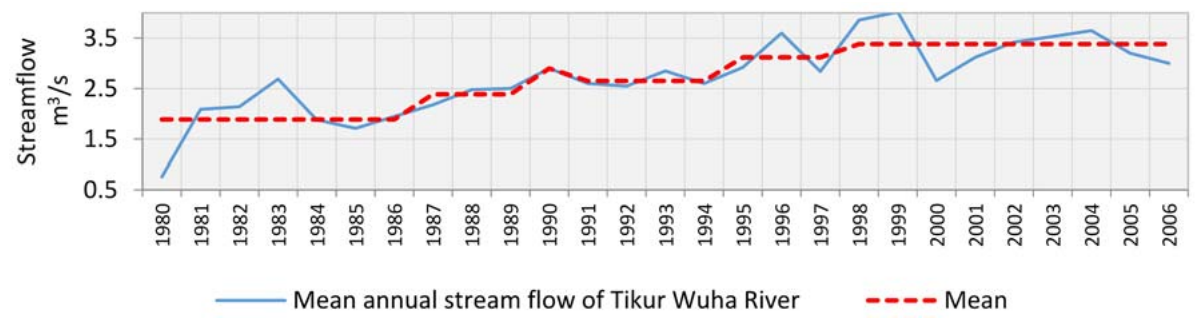

Figure 6. Regime shift in Tikur Wuha streamflow.

\subsubsection{Variability in Potential Evapotranspiration (ET)}

Time series of Evapotranspiration (ET) was derived by the Penman-Monteith model $[59,60]$. The model uses five climate variables (minimum and maximum temperature, relative humidity, wind speed, and sun-shine hours) to compute the potential evapotranspiration (ET). As shown in Figure 7, significant drops were exhibited in 1988 (strong La Niña year) and in 1995 (weak La Niña). An upward shift was also depicted in 1994 (Moderate El Niño year). Nevertheless, there was no significant trend in the potential evapotranspiration.

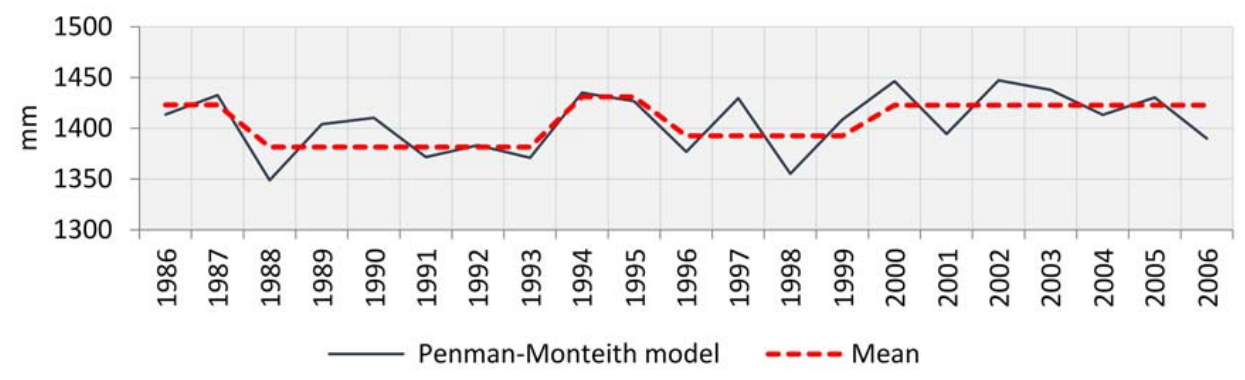

Figure 7. Regime shifts in potential evaporation as computed by the Penman-Monteith model. 
3.2.5. Land Use/Cover Change as a Potential Anthropogenic Factor in Affecting the Lake Hydrology

Often, the effect of climate change and human activities on hydrological variables cannot be distinguished [61]. Climate and land use are key factors controlling the hydrological behavior of a catchment $[62,63]$. The assessment of the impacts of such diverse environmental changes is still one of the main challenges in recent hydrological research [64]. In terms of spatial scales, distinguishing the impact of land use changes on hydrology from the impact of climatic variability is more difficult at the catchment than at the plot or small catchment scale [65]. Many studies have considered these factors separately; however, they do not act in isolation, but rather interact to affect ecosystem structure and function [66].

A number of studies were performed in Lake Hawassa catchment in relation to the impact of land use/ cover of the local water cycle. Abrha [67] assessed the impact of land use/ cover changes on ground water recharge. The author found a significant change in ground water recharge is due to land use and land covers change (especially vegetation cover reduction) in the catchment. Gebreegziagher [10] also recognized the land-use change in the watershed of Lake Hawassa as the most likely cause for the increasing tendency of runoff overtime in combination with the effect of climate variability and climate change. The land use/ land cover dynamics of the watershed is presented in Table 2 below.

Table 2. Land use/ land cover changes in the catchment (units are in $\mathrm{km}^{2}$ ) (After Abrha [67]).

\begin{tabular}{cccccc}
\hline & Agriculture & Grass Land & Bush Land & Shrubby Wood Land & Urban Area \\
\hline 1973 & 323.3 & 15.5 & 165.9 & 704.7 & 6 \\
1986 & 466.2 & 59.5 & 180.3 & 548.6 & 8 \\
2000 & 565.9 & 68.7 & 145.6 & 448.2 & 13 \\
\hline
\end{tabular}

As shown in the above table, on average, $9.5 \mathrm{~km}^{2} /$ year of shrub wood land has been converted into other land use types mostly into agricultural lands $\left(9 \mathrm{~km}^{2} /\right.$ year $)$.

\subsubsection{Interaction of Geomorphological Processes with Lake Hydrology}

The period 1996-1998 was extremely wet in the study area [10] and parallel to this, three consecutive surface cracks/gullies have developed in the years 1996, 1997 and 1998. The first gully developed in April 1996 with an extent of about $150 \mathrm{~m}$ length and $3 \mathrm{~m}$ depth after inundation of the area with massive flood following an above normal precipitation. The second gully developed across the central part of the catchment in April 1997 with the total length slightly more than $800 \mathrm{~m}$ and visible depth in the range of 3-8 $\mathrm{m}$. The extent of this gully increased finally reaching a length of $2.4 \mathrm{~km}$ with depth ranges of 8-12 m [68]. Hydrologically, these gullies are important features that facilitate fast transfer of surface water into the aquifer and then to the lake. Field evidences also indicate the positive role of newly formed gullies that act as conduit to ground water inflow from the elevated areas to Lake Hawassa [69]. Unfortunately, these gullies developed in a region of the catchment which was not monitored using stream discharge gauges.

\subsection{Results of Coherence Analysis}

Figure 8 shows the result of coherence analysis. The values of coherency ( $y$-axis) versus frequency ( $x$-axis) between the Niño3.4 ENSO index and monthly mean lake level changes. 


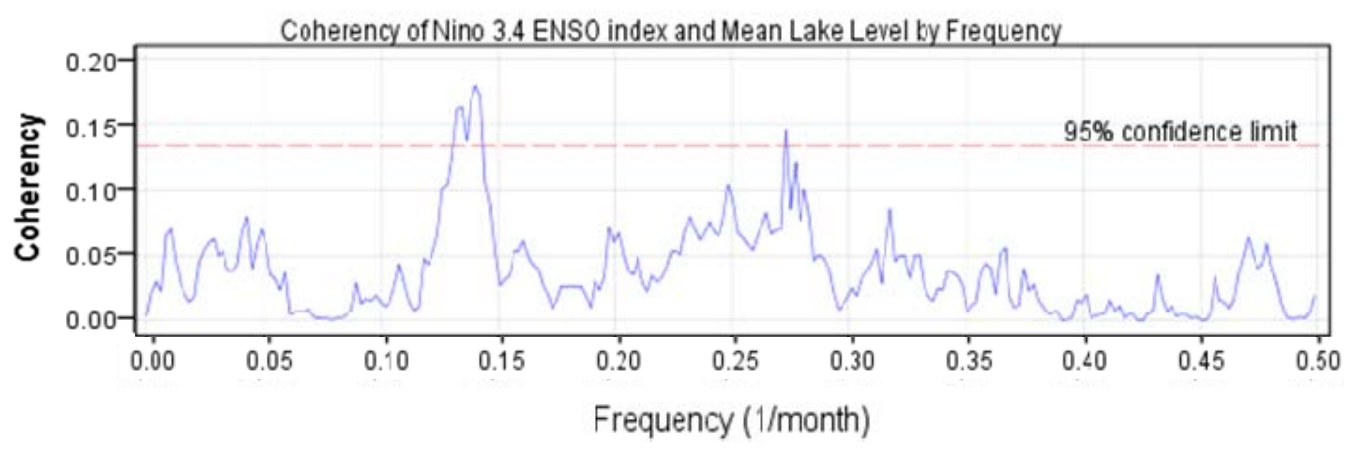

Figure 8. Coherence between ENSO index and lake level variability in frequency domain.

As evidenced by the result of coherence analysis (Figure 8), the cyclic nature of Lake Hawassa water level variability has significant linear relationship to the climate variability at some frequencies. It appears that there are two significant peaks at 95\% confidence limit. Further probe to the prominent peak reveals that the peak occurred at a frequency between $0.13-0.14 \mathrm{cycle} / \mathrm{month}$ or $1.56-1.68$ cycle/year. This corresponds to a period of about $7.14-7.69$ months $(=1 / 0.14-1 / 0.13)$ or a dominant average periodicity (coincident cycle) of about 7.4 months which is likely associated with the time span between the two wet periods that extend from June-September (main rainy season) and March and May (little rain). A relevant finding was reported by Namdar-Ghanbari and Bravo [70] in which the levels of Great Lakes and Trans-Niño Index (TNI) show significant coherence in the frequency range (3-7) ${ }^{-1}$ cycles/year.

The vital importance of the above analyses is the detection of significant coherence at some specific frequency ranges and confirmed that significant portion of the lake level variability is caused by factors operating on a scale larger than processes in the watershed.

\section{Conclusions}

The diverse statistical analyses of this chapter provide a plausible explanation for the interaction between the local hydrology and climate anomalies at Pacific. More importantly, the evidences helped us to conclude about the effect of ENSO phenomena and climate shifts on the local hydrology of the lake. Generally, it is observed that high lake level tends to follow moderate to strong El Niño and the reverse is true for La Niña events.

The two prominent climate events which strongly influence the hydrology of Lake Hawassa are: the climate shift of North Pacific Ocean that occurred in 1976/1977 and the El Niño events that occurred in 1972-1973, 1982-1983, 1997-1998, and 2009-2010.

The general suggestions of this study supported the idea of Szestzay [71] in which water level fluctuations of closed lakes are considered as meaningful indicators of climatic changes. Nevertheless, there is no simple linear relationship between climate and lake level variability as shown in this study. The increasing water level of Lake Hawassa can be explained by the interaction of climate with a special emphasis on El Niño events, land use change and geomorphological processes which influence drainage density of the catchment and therefore residence time of water and total discharge. The occurrence of El Niño events alone cannot explain the increase in lake water level but is triggering processes which result in the observed dynamics.

The association of extreme lake level rises of Lake Hawassa to the occurrences of El Niño events (as in the case of 1998 flood) could have two management dimensions. On one hand, it would be difficult to mitigate the problem because of its dependence on macro-scale processes and on the other hand, those large El Niño events which are notorious for their extreme floods are acceptably predictable within period at lead times of up to two years [72]. Climate forecasts are also shown to be more accurate during El Niño and La Niña events and furthermore, stronger ENSO events lead to greater predictability of the climate [73]. These are opportunities to get alarms against the urgency 
of flood occurrences and it is recommended to mainstream the updated information regarding the probable occurrences of ENSO events and climate shifts in a regular emergency and preparedness actions to reduce the impact of potential flood risks.

Acknowledgments: The authors thanks the DAAD and Ethiopian government, who supported this study under the "engineering capacity building program-ecbp" project with a three-year scholarship provided to the first author. The anonymous reviewers are gratefully acknowledged for their constructive comments.

Author Contributions: All figures and tables and manuscript writing were done by Mulugeta Dadi Belete and Bernd Diekkrüger. The Ph.D. Thesis where the manuscript was derived from was supervised and examined by Bernd Diekkrüger and Jackson Roehrig.

Conflicts of Interest: The authors declare no conflict of interest.

\section{Appendix A. SynThesis of RSI Output}

Table A1. Synthesis of RSI output.

\begin{tabular}{|c|c|c|c|c|c|c|c|}
\hline & Av.Lake Depth (m) & RSI & Mean & Weighed & Length & $p$ & Outliers \\
\hline 1970 & 19.64 & 0.00 & 19.70 & 19.68 & 8 & & \\
\hline 1971 & 19.83 & 0.00 & 19.70 & 19.68 & 8 & & \\
\hline 1972 & 20.26 & 0.00 & 19.70 & 19.68 & 8 & & 0.76 \\
\hline 1973 & 19.92 & 0.00 & 19.70 & 19.68 & 8 & & \\
\hline 1974 & 19.53 & 0.00 & 19.70 & 19.68 & 8 & & \\
\hline 1975 & 19.37 & 0.00 & 19.70 & 19.68 & 8 & & \\
\hline 1976 & 19.36 & 0.00 & 19.70 & 19.68 & 8 & & \\
\hline 1977 & 19.67 & 0.00 & 19.70 & 19.68 & 8 & & \\
\hline 1978 & 20.40 & 0.63 & 20.12 & 20.10 & 9 & 0.02 & \\
\hline 1979 & 20.74 & 0.00 & 20.12 & 20.10 & 9 & & 0.68 \\
\hline 1980 & 20.33 & 0.00 & 20.12 & 20.10 & 9 & & \\
\hline 1981 & 19.86 & 0.00 & 20.12 & 20.10 & 9 & & \\
\hline 1982 & 19.72 & 0.00 & 20.12 & 20.10 & 9 & & \\
\hline 1983 & 20.15 & 0.00 & 20.12 & 20.10 & 9 & & \\
\hline 1984 & 20.22 & 0.00 & 20.12 & 20.10 & 9 & & \\
\hline 1985 & 19.77 & 0.00 & 20.12 & 20.10 & 9 & & \\
\hline 1986 & 19.90 & 0.00 & 20.12 & 20.10 & 9 & & \\
\hline 1987 & 20.27 & 0.88 & 20.43 & 20.43 & 6 & 0.06 & \\
\hline 1988 & 20.32 & 0.00 & 20.43 & 20.43 & 6 & & \\
\hline 1989 & 20.71 & 0.00 & 20.43 & 20.43 & 6 & & \\
\hline 1990 & 20.78 & 0.00 & 20.43 & 20.43 & 6 & & \\
\hline 1991 & 20.33 & 0.00 & 20.43 & 20.43 & 6 & & \\
\hline 1992 & 20.17 & 0.00 & 20.43 & 20.43 & 6 & & \\
\hline 1993 & 20.72 & 1.10 & 21.20 & 21.16 & 10 & 0.001 & \\
\hline 1994 & 20.70 & 0.00 & 21.20 & 21.16 & 10 & & 0.95 \\
\hline 1995 & 20.53 & 0.00 & 21.20 & 21.16 & 10 & & 0.69 \\
\hline 1996 & 20.92 & 0.00 & 21.20 & 21.16 & 10 & & \\
\hline 1997 & 21.33 & 0.00 & 21.20 & 21.16 & 10 & & \\
\hline 1998 & 21.98 & 0.00 & 21.20 & 21.16 & 10 & & 0.53 \\
\hline 1999 & 21.90 & 0.00 & 21.20 & 21.16 & 10 & & 0.59 \\
\hline 2000 & 21.25 & 0.00 & 21.20 & 21.16 & 10 & & \\
\hline 2001 & 21.31 & 0.00 & 21.20 & 21.16 & 10 & & \\
\hline 2002 & 21.37 & 0.00 & 21.20 & 21.16 & 10 & & \\
\hline 2003 & 20.87 & -0.29 & 21.00 & 20.99 & 8 & 0.34 & \\
\hline 2004 & 20.58 & 0.00 & 21.00 & 20.99 & 8 & & \\
\hline 2005 & 20.56 & 0.00 & 21.00 & 20.99 & 8 & & \\
\hline 2006 & 20.72 & 0.00 & 21.00 & 20.99 & 8 & & \\
\hline 2007 & 21.46 & 0.00 & 21.00 & 20.99 & 8 & & 0.93 \\
\hline 2008 & 21.47 & 0.00 & 21.00 & 20.99 & 8 & & 0.92 \\
\hline 2009 & 21.19 & 0.00 & 21.00 & 20.99 & 8 & & \\
\hline 2010 & 21.16 & 0.00 & 21.00 & 20.99 & 8 & & \\
\hline
\end{tabular}

Where, RSI: Regime Shift Index; Mean: Equal-weighed arithmetic means of the regimes; Weighed: Weighed means of the regimes using the Huber's weight function with the parameter $=1$; Length: Length of the regimes; $P$ : Significance level of the difference between the mean values of the neighboring regimes based on the Student's two-tailed $t$-test with unequal variance; Outliers: Weight of the deviations from the weighed mean greater than 1 standard deviation(s). 


\section{References}

1. Lenters, J.D.; Kratz, T.K.; Bowser, C.J. Effects of climate variability on lake evaporation: Results from a long-term energy budget study of Sparkling Lake, Northern Wisconsin (USA). J. Hydrol. 2005, 308, $168-195$. [CrossRef]

2. Limgis. Winter School on Essentials in Limnology and Geographic Information System (GIS). 2001. Available online: http:/ / wgbis.ces.iisc.ernet.in/energy/finance/New/limgis.html (accessed on 5 February 2013).

3. Lamb, H.H. Climate in the 1960s. Geogr. J. 1966, 132, 183-212. [CrossRef]

4. Flohn, H. East African rains of 1961/1962 and the abrupt change of the White Nile Discharge. Palaeoecol. Afr. 1987, 18, 3-18.

5. Nicholson, S.E. Environmental change within the historical period. In The Physical Geography of Africa; Goudie, A.S., Adams, W.M., Orme, A., Eds.; Oxford University Press: Oxford, UK, 1995.

6. Arnell, N.; Bates, B.; Lang, H.; Magnusson, J.J.; Mulholland, P. Climate Change 1995: Impacts, Adaptations and Mitigations of Climate Change: Scientific Technical Analyses; Cambridge Univ. Press: Cambridge, UK, 1996.

7. Bergonzini, L. Bilanshydriques de lacs (Kivu, Tanganyika, Rukwa and Nyassa) du riftest-africain Mus. R. Afr. Centr. Tervuren Ann. Sc. Geol. 1998, 103, 1-183.

8. Goerner, A.; Jolie, E.; Gloaguen, R. Non-climatic growth of the saline Lake Beseka, Main Ethiopian Rift. J. Arid Environ. 2009, 73, 287-295. [CrossRef]

9. Belay, E.A. Growing lake with growing problems: Integrated Hydrogeological Investigation on Lake Beseka, Ethiopia. Ph.D. Thesis, Rheinischen Friedrich-Wilhelms-Universität, Bonn, Germany, 2009.

10. Gebreegziabher, Y. Assessment of the Water Balance of Lake Awassa Catchment, Ethiopia. Master's Thesis, International Institute for Geo-information Science and Earth Observation, Enschede, The Netherlands, 2004.

11. WWDSE (Water Works Design and Supervision Enterprise). The Study of Lake Awassa Level Rise; Southern Nations Nationalities and Peoples Regional State; Water, Mines and Energy Resources Development Bureau: Addis Ababa, Ethiopia, 2001.

12. WRDB (Water Resources Development Bureau). Study of Pollution of Lakes and Rivers; AG Consulting Hydrogeologists and Engineers Plc: Addis Ababa, Ethiopia, 2007.

13. Ayenew, T. Environmental implications of changes in the levels of lakes in the Ethiopian Rift since 1970. Reg. Environ. Chang. 2004, 4, 192-204. [CrossRef]

14. Deganovsky, A.M.; Getahun, B.A. Water balance and level regime of Ethiopian lakes as integral indicators of climate change. In Proceedings of the 12th World Lake Conference (Taal2007), Jaipur, India, 28 October-2 November 2008.

15. Ayenew, T.; Gebreegziabher, Y. Application of a spreadsheet hydrological model for computing the long-term water balance of Lake Awassa, Ethiopia. Hydrol. Sci. J. 2006, 51, 418-431. [CrossRef]

16. Gebremichael, H. Modeling and Forcasting Hawassa Lake Level Fluctuation. Master's Thesis, Addis Ababa University, Addis Ababa, Ethiopia, 2007.

17. Shewangizaw, D. Assessing the Effect of Land Use Changes on the Hydraulic Regime of Lake Hawassa. Master's Thesis, Addis Ababa University, Addis Ababa, Ethiopia, 2010.

18. Wagesho, N.; Goel, N.K.; Jain, M.K. Investigation of non-stationarity in hydro-climatic variables at Rift Valley Lakes Basin of Ethiopia. J. Hydrol. 2012, 444, 113-133. [CrossRef]

19. Wallace, J.M.; Gutzler, D.S. Teleconnections in the geopotential height field during the Northern Hemisphere winter. Mon. Weather Rev. 1981, 109, 784-812. [CrossRef]

20. MoWR. The Federal Democratic Republic of Ethiopia-Ministry of Water Resources: Rift Valley Lakes Basin Integrated Resources Development Master Plan Study Project. Phase 3 Report: Lake Hawassa Sub-basin Integrated Watershed Management Feasibility Study. Part 1 and 2; Halcrow Group Limited and Generation Integrated Rural Development (GIRD) Consultants: Addis Ababa, Ethiopia, 2010.

21. Belete, M.D.; Diekkrüger, B.; Roehrig, J. Characterization of the water level variability of the main Ethiopian Rift Valley Lakes. Hydrology 2015, 3, 1. [CrossRef]

22. Legesse, D.; Vallet-Coulomb, C.; Gasse, F. Hydrological response of a catchment to climate and land use changes in Tropical Africa: Case study South Central Ethiopia. J. Hydrol. 2003, 275, 67-85. [CrossRef]

23. Legesse, D.; Vallet-Coulomb, C.; Gasse, F. Analysis of the hydrological response of a tropical terminal lake, Lake Abiyata (Main Ethiopian Rift Valley) to changes in climate and human activities. Hydrol. Process 2004, 18, 487-504. [CrossRef] 
24. Dessie, N. Hydrogeological Investigation of Lake Hawassa Catchment. Master's Thesis, Addis Ababa University, Addis Ababa, Ethiopia, 1995.

25. Thomson, R.E.; Emery, W.J. Time-Series Analysis Methods: Data Analysis Methods in Physical Oceanography, 2nd ed.; Elsevier Science: Amsterdam, The Netherlands, 2001.

26. Mann, H.B. Non-parametric tests against trend. Econometrica 1945, 13, 245-259. [CrossRef]

27. Kendall, M.G. Rank Correlation Measures; Charles Griffin: London, UK, 1975.

28. Tabari, H.; Marofi, S. Changes of pan evaporation in the West of Iran. Water Resour. Manag. 2011, 25, 97-111. [CrossRef]

29. Tabari, H.; Somee, B.S.; Zadeh, M.R. Testing for long-term trends in climatic variables in Iran. Atmos. Res. 2011, 100, 132-140. [CrossRef]

30. Steele, J.H. Regime shifts in fisheries management. Fish Res. 1996, 25, 19-23. [CrossRef]

31. Hare, S.R.; Mantua, N.J. Empirical evidence for North Pacific regime shifts in 1977 and 1989. Prog. Ocean. 2000, 47, 103-145. [CrossRef]

32. Overland, J.E.; Percival, D.B.; Mofjeld, H.O. Regime shifts and red noise in the North Pacific. Deep Sea Research. Part I. Oceanogr. Res. Pap. 2006, 53, 582-588. [CrossRef]

33. Rodionov, S.N. A sequential algorithm for testing climate regime shifts. Geophys. Res. Lett. 2004, 31 , L09204. [CrossRef]

34. Rodionov, S.N. A brief overview of the regime shift detection methods. In Large-Scale Disturbances (Regime Shifts) and Recovery in Aquatic Ecosystems: Challenges for Management toward Sustainability; Velikova, V., Chipev, N., Eds.; UNESCO-ROSTE/BAS Workshop on Regime Shifts: Varna, Bulgaria, 2005.

35. TSOA (Texas State Auditor's Office). Data Analysis: Analyzing Data-Trend Analysis-2; Methodology Manual rev. 5/95; Texas State Auditor's Office: Austin, TX, USA, 1995.

36. Breaker, L.C. A closer look at regime shifts based on coastal observations along the eastern boundary of the North Pacific. Cont. Shelf Res. 2007, 27, 2250-2277. [CrossRef]

37. Biltoft, C.A.; Eric, R.P. Spectral coherence and the statistical significance of turbulent flux computations. J. Atmos. Ocean. Technol. 2009, 26, 403-409. [CrossRef]

38. Hernando, O.; Bellegem, S.V. Coherence Analysis of Non-Stationary Time Series: A Linear Filtering Point of View; UCL_EUEN/CORE—Center for Operations Research and Econometrics: Louvain, Belgium, 2006.

39. Koopmans, L.H. The Spectral Analysis of Time Series; Academic Press: New York, NY, USA, 1974.

40. Bendant, J.S.; Piersol, A.G. Random Data Analysis and Measurement Procedures, 2nd ed.; Wiley: New York, NY, USA, 1986.

41. Jenkins, G.M.; Watts, D.G. Spectral Analysis and Its Applications; Holden Day: San Francisco, CA, USA, 1968.

42. Bloomfield, P. Fourier Analysis of Time Series: An Introduction; Wiley: New York, NY, USA, 1976.

43. Korecha, D.; Barnston, A.G. Predictability of June-September rainfall in Ethiopia. Am. Meteorol. Soc. Mon. Weather Rev. 2007, 135, 628-650. [CrossRef]

44. Babu, A. The impact of Pacific sea surface temperature on the Ethiopian rainfall. In Presented at Workshop on High-Impact Weather Predictability Information System for Africa and AMMA-THORPEX Forecasters' Handbook, Trieste, Italy, 5-8 October 2009.

45. Barnston, A.G.; Chelliah, M.; Goldenberg, S.B. Documentation of a highly ENSO-related SST region in the equatorial Pacific. Atmos.-Ocean 1997, 35, 367-383.

46. GEOS. Notes on Time Series Analysis; University of Arizona: Tucson, AZ, USA, 2013.

47. Namdar-Ghanbari, R.; Bravo, H.R.; Magnuson, J.J.; Hyzer, W.G.; Benson, B.J. Coherence between lake ice cover, local climate and teleconnections (Lake Mendota, Wisconsin). J. Hydrol. 2009, 374, 282-293. [CrossRef]

48. Belete, A. Climate Change Impact on Lake Abaya Water Level. Master's Thesis, Addis Ababa University, Addis Ababa, Ethiopia, 2009.

49. Mercier, F.; Cazenave, A.; Maheu, C. Inter-annual lake level fluctuations (1993-1999) in Africa from Topex/Poseidon: Connections with ocean-atmosphere interactions over the Indian Ocean. Glob. Planet. Chang. 2002, 32, 141-163. [CrossRef]

50. Tereshchenko, I.; Filonov, A.; Gallegos, A.; Monzo'n, C.; Rodrı'guez, R. 1997-98 and the hydrometeorological variability of Chapala, a shallow tropical lake in Mexico. J. Hydrol. 2002, 264, 133-146. [CrossRef]

51. Strub, P.T.; James, C. Altimeter-derived surface circulation in the large-scale NE Pacific Gyres.: Part 2: 1997-1998 anomalies. Prog. Ocean. 2002, 53, 185-214. [CrossRef] 
52. Marucci, S.D. The Impact of Southern Oscillation Phenomenon on the Panama Canal and Its Markets. In Proceedings of the International Association of Maritime Economists Annual Conference, Panama City, Panama, 13-15 November 2002.

53. Sponberg, K. Navigating the Numbers of Climatological Impact. Compendium of Climatological Impacts; University Corporation for Atmospheric Research 1, National Oceanic and Atmospheric Administration, Office of Global Programs: Boulder, CO, USA, 1999.

54. Miller, A.J.; Cayan, D.R.; Barnett, T.P.; Graham, N.E.; Oberhuber, J.M. The 1976-77 climate shift of the Pacific Ocean. Oceanography 1994, 7, 21-26. [CrossRef]

55. Yletyinen, J.; Blenckner, T.; Biggs, R. North Pacific Ocean. In Regime Shifts Database; Stockholm Resilience Centre Stockholm University: Stockholm, Sweden, 2012. Available online: http:/ /www.regimeshifts.org/ about/item/406-north-pacific-ocean (accessed on 10 January 2013).

56. Swanson, K.L.; Tsonis, A.A. Has the climate recently shifted? Geophys. Res. Lett. 2009, 36, L06711. [CrossRef]

57. Peterson, W.T.; Schwing, F.B. A new climate regime in Northeast Pacific Ecosystems. Geophys. Res. Lett. 2003, 30, 1-4. [CrossRef]

58. Niebauer, H.J. Variability in Bering Sea ice cover as affected by a "regime shift" in the North Pacific in the period 1947-96. J. Geophys. Res. 1998, 103, 27717-27737. [CrossRef]

59. Penman, H.L. Natural evaporation from open water, bare soil, and grass. Proc. R. Soc. Lond. A 1948, 193, 120-146. [CrossRef]

60. Monteith, J.L. Evaporation and environment. In Symposium of the Society for Experimental Biology, the State and Movement of Water in Living Organisms; Fogg, G.E., Ed.; Academic Press Inc.: New York, NY, USA, 1965; pp. 205-234.

61. Uhlenbrook, S. Climate and man-made changes and their impacts on catchments. In Proceedings of the Joint Conference of APLU and ICA, Prague, Czech, 23-26 June 2009.

62. Hörmann, G.; Horn, A.; Fohrer, N. The evaluation of land-use options in mesoscale catchments-prospects and limitations of eco-hydrological models. Ecol. Model. 2005, 187, 3-14. [CrossRef]

63. Li, Z.; Liu, W.Z.; Zhang, X.C.; Zheng, F.L. Impacts of land use change and climate variability on hydrology in an agricultural catchment on the Loess Plateau of China. J. Hydrol. 2009, 377, 35-42. [CrossRef]

64. Elfert, S.S.; Bormann, H. Simulated impact of past and possible future land use changes on the hydrological response of the Northern German lowland 'Hunte' catchment. J. Hydrol. 2010, 383, 245-255. [CrossRef]

65. Archer, D. Scale effects on the hydrological impact of upland afforestation and drainage using indices of flow variability: The River Irthing, England. Hydrol. Earth Syst. Sci. 2003, 7, 325-338. [CrossRef]

66. Kulakowski, D.; Bebi, P.; Rixen, C. The interacting effects of land use change, climate change and suppression of natural disturbances on landscape forest structure in the Swiss Alps. Oikos 2011, 120, 216-225. [CrossRef]

67. Abrha, L. Assessing the Impact of Land Use and Land Cover Change on Ground Water Recharge Using RS and GIS: A Case of Awassa Catchment, South Ethiopia. Master's Thesis, Addis Ababa University, Addis Ababa, Ethiopia, 2007.

68. Yirgu, G.; Paola, D.; Kebede, G.M.; Hagos, F.; Teferi, M.A.; Tilahun, G.; Gemetesa, N. Study Report on Ground Fracturing in the Muleti Area, Awasa Zuria Woreda; Addis Ababa University: Addis Ababa, Ethiopia; SNNPR Professional Paper: Hawassa, Ethiopia, 1997.

69. Ayenew, T. Water management problems in the Ethiopian rift: Challenges for development. J. Afr. Earth Sci. 2007, 48, 222-236. [CrossRef]

70. Namdar-Ghanbari, R.; Bravo, H.R. Coherence between atmospheric teleconnections, Great Lakes water levels and regional climate. Adv. Water Resour. 2008, 31, 1284-1298. [CrossRef]

71. Szesztay, K. Water balance and water level fluctuation of lakes. Hydrol. Sci.-Bull. 1974, 19, 73-84. [CrossRef]

72. Chen, D.; Mark, A.C.; Alexey, K.; Stephen, E.Z.; Daji, H. Predictability of Niño over the past 148 years. Nature 2004, 428, 733-736. [CrossRef] [PubMed]

73. Goddard, L.; Dilley, M. Catastrophe or opportunity. J. Clim. 2005, 18, 651-665. [CrossRef]

(C) 2017 by the authors. Licensee MDPI, Basel, Switzerland. This article is an open access article distributed under the terms and conditions of the Creative Commons Attribution (CC BY) license (http:/ / creativecommons.org/licenses/by/4.0/). 